Similar treatment with $200 \mathrm{mgm}$, methionine in $0.5 \mathrm{~N}$ hydrochloric acid by stomach tube, $50 \mathrm{mgm}$. glutathione intra-peritoneally, or $50 \mathrm{mgm}$. glucose intraperitoneally, given separately to groups of rats over three days did not affect susceptibility to carbon tetrachloride poisoning although methionine ${ }^{5,6,7}$ and glutathione have been reported to be useful therapeutic agents.

It is clear that the administration of substances which stimulate the synthesis of pyridine nucleotides affords protection against the acute toxic effects of large doses of carbon tetrachloride. Whatever the manner by which carbon tetrachloride affects mitochondrial structure and increases permeability, this study supports the idea that it is the loss of respiratory cofactors which inactivates mitochondrial enzymes and kills cells ${ }^{1}$. Increased tissue concentrations of pyridine nucleotides presumably result in the maintenance of higher mitochondrial coenzyme levels and thus sustain respiratory activity in the presence of carbon tetrachloride and ensure the continuance of tissue metabolism during the critical period of maximum carbon tetrachloride effect.

C. H. Gallagher

R. A. SIMMONDS

McMaster Laboratory

Commonwealth Scientific and

Industrial Research Organization,

Parramatta Road, Glebe, Sydney.

1 Christie, G. S., and Judah, J. D., Proc. Roy. Soc., B, 142, 241 (1954). - Preiss, J., and Handler, P., J. Biol. Chem., 233, 488 (1958).

Williams, J. N., Feigelson, P., and Elvehjem, C. A., J. Biol. Chem., 187, $597(1050)$

Chaloupka, M. M., Williams, J. N., Reynolds, M. S., and EIvehjem, C. A., $J$. Nutrition, 63, $361(1957)$

- Eddy, J. H., J.Amer. Med. Ass., 128, 994 (1945)

Patwardhan, M. V ., Ramalingaswami, V., Sriramachari, S., and Patwardhan, V. N., Indian J. Med. Sci., 8, 15 (1954). Cited in "Shiels, D. O., Med. J. Aust., 11, 729 (1958).

\section{Implications of Restricting Cows to a Clover- free Diet in Order to Reduce the Strontium Content of Milk}

Vose and Koontz ${ }^{1}$ have suggested that because mixed legume-grass herbage contains a higher level of strontium than grass it would be desirable to restrict dairy cows to an all-grass diet if the level of strontium-90 in milk ever rose to a level giving cause for concern. In the same communication these authors report that the uptake of strontium by herbage is directly related to the uptake of calcium.

Since clovers usually contain substantially higher contents of magnesium, cobalt and copper than grasses, any attempt to restrict clover growth on a large scale could have very far-reaching consequences. For example, the incidence of hypomagnesæmic tetany in sheep and cattle, related as it appears to be to magnesium intake, might be seriously affected by any widespread attempt to reduce the proportion of clover in the diet of stock.

There is also the question of where the stock is to obtain the level of calcium necessary to maintain the calcium content of the milk if the intake of calcium is curtailed by reducing the clover content of the herbage. Because of the increasing tendency in the United Kingdom for farmers to adopt a policy of feeding the maximum quantity of grass to lactating cows in order to reduce the consumption of the more expensive concentrates, this is a matter of great importance. According to Corrie ${ }^{2}$, the amount of calcium in the diet should not be less than 11-12 gm. per gallon of milk produced, and since the average Table 1. Strontium, Calcium AND Magingsum Contents of
Forage Plants on a Dry-Matter Basis

\begin{tabular}{|c|c|c|c|c|}
\hline Sample & $\begin{array}{c}\mathrm{Sr} \\
\text { (p.p.m.) }\end{array}$ & $\begin{array}{l}\mathrm{Ca} \\
\%\end{array}$ & $\begin{array}{l}\mathrm{Mg} \\
\%\end{array}$ & $\begin{array}{l}\mathrm{8r} / \mathrm{Ca} \\
\times 10\end{array}$ \\
\hline Brussels sprout leaves & $47 \cdot 1$ & $2 \cdot 50$ & $0 \cdot 182$ & 188 \\
\hline Cauliflower leaves & $54 \cdot 0$ & $3 \cdot 26$ & $0 \cdot 179$ & \\
\hline Broccoli leaves & $27 \cdot 9$ & 1.64 & 0.117 & 17 \\
\hline Beet pulp & $23 \cdot 6$ & 0.555 & 0.177 & 425 \\
\hline Turnip cores & $12 \cdot 7$ & 0.518 & $0 \cdot 104$ & 245 \\
\hline Turnip cores & $18 \cdot 9$ & 0.511 & 0.193 & 370 \\
\hline Clover-variety Kersey & $36 \cdot 6$ & $2 \cdot 15$ & 0.234 & \\
\hline Clover-variety Kersey & 36.5 & $2 \cdot 55$ & 0.241 & 143 \\
\hline $\begin{array}{l}\text { Perennial rye-grass + } \\
\text { wild white clover }\end{array}$ & $19 \cdot 4$ & 1.79 & 0.160 & \\
\hline $\begin{array}{l}\text { Perennial rye-grass }+ \\
\text { wild white clover }\end{array}$ & $18 \cdot 9$ & $1 \cdot 28$ & $0 \cdot 143$ & \\
\hline Pereunial rye-grass & 10.9 & $0 \cdot 414$ & 0.119 & \\
\hline Perennial rye-grass & $7 \cdot 59$ & 0.347 & 0.096 & \\
\hline
\end{tabular}

milk-production ration consisting entirely of foods of vegetable origin $\left(3 \frac{1}{2} \mathrm{lb}\right.$.) furnishes only about $2 \cdot 5 \mathrm{gm}$. calcium. it is evident that the bulk of the calcium content of milk is derived from the herbage grazed when no mineral mixture is supplied. In the case of a dairy cow yielding 5 gallons of milk per day during the summer months, the quantity of calcium supplied by a pure grass diet falls short of the lactation requirement alone, even in favourable conditions of uptake and calcium content. For example, an Ayrshire cow consuming as much as $12 \mathrm{kgm}$. of dry matter per day of grass of a relatively high calcium content, say 0.4 per cent calcium in the dry matter, will be receiving only $48 \mathrm{gm}$. calcium as compared with the 55-60 gm. required for milk production alone. Under such eonditions one would expect the skeletal reserves of calcium to be rapidly depleted.

While some feeding stuffs other than clovers could. supply additional calcium and magnesium, it appears unlikely that they could do so without a concomitant increase in strontium content. The following figures for the contents of strontium, calcium and magnesium in various kinds of fodder, illustrate this difficulty. Calcium was determined by a modification of the Lundegardh technique described by Mitchell ${ }^{3}$ in which phosphate in the plant extracts was removed by ion-exchange prior to excitation in the air-acetylene flame. Strontium and magnesium were determined by the method of Farmer ${ }^{4}$.

The leaves of brassicas generally contain even higher concentrations of calcium than those of legumes and, as the figures in Table 1 suggest, these are related to correspondingly higher contents of strontium. Of the samples analysed, those with the most unfavourable ratios of strontium to calcium were the roots and the samples of pure perennial ryegrass.

Since brassicas are directly consumed by humans and form a substantial proportion of their diet the amounts of strontium ingested in such foods may well be comparable to the amounts obtained from milk. It is clear that any general attempt to reduce the intake of strontium -90 by humans, either by selecting foodstuffs containing low contents of strontium, or by restricting dairy cows to an all-grass diet would have very serious repercussions throughout agricultural industry as well as producing dietary and nutritional problems the implications of which do not seem to have been appreciated.

Edinburgh and East of Scotland

David Purves College of Agriculture, 13 George Square, Edinburgh, 8.

1 Vose, P. B., and Koontz, H. V., Nature, 183, 1447 (1959).

2 Corrie, F. E. 'Some Elements of Plants and Anirnals', 6 (Fertiliser Journal Ltd,, London, 1948).

3 Mitchell, R. L., 'The Spectrographic Analysis of Soils, Plants and Related Materials', 35 (Technical Communication No. 44, Commonwealth Bureau of Soil Science, 1948).

monwealth Bureau of Soil Science, 1948)
4 Farmer, V. C., Spectrochimica Acta, 4, 224 (1950). 